\title{
Detection of food intake in a marine mammal using marine osmolytes and their analogues as dietary biomarkers
}

\author{
Regina Eisert ${ }^{1,5, *}$, Olav T. Oftedal ${ }^{1}$, Michael Lever ${ }^{2}$, Sven Ramdohr ${ }^{3}$, \\ Bernhard H. Breier ${ }^{4}$, Graham K. Barrell ${ }^{5}$ \\ ${ }^{1}$ Department of Conservation Biology, Smithsonian National Zoological Park, 3001 Connecticut Avenue NW, \\ Washington, DC 20008, USA \\ ${ }^{2}$ Canterbury Health Laboratories, PO Box 151, Christchurch, New Zealand \\ ${ }^{3}$ Alfred-Wegener-Institut für Polar- und Meeresforschung, Am Handelshafen 12, 27570 Bremerhaven, Germany \\ ${ }^{4}$ Liggins Institute, University of Auckland, Faculty of Medical and Health Sciences, Private Bag 92019, Auckland, New Zealand \\ ${ }^{5}$ Animal and Food Sciences Division, Lincoln University, PO Box 84, Canterbury, New Zealand
}

\begin{abstract}
We report a novel method of investigating foraging in marine mammals based on detecting biomarkers of strictly dietary origin in blood. Arsenobetaine (AsB), the arsenic analogue of the osmolyte glycine betaine, and trimethylamine $N$-oxide (TMAO), an osmolyte used by marine fish and invertebrates, were measured in plasma of lactating Weddell seals Leptonychotes weddellii during the postpartum fast and at different stages of lactation. Plasma dietary biomarker concentrations were low in early lactation (<14 d postpartum [d p.p.]; AsB: $5.5 \pm 2$ ppb As, TMAO: $66 \pm$ $20 \mu \mathrm{mol} \mathrm{l}^{-1}$ ) and increased 10-fold in late lactation ( $\geq 27 \mathrm{~d}$ p.p.; AsB: $57 \pm 17$ ppb As, TMAO: $685 \pm$ $\left.199 \mu \mathrm{mol} \mathrm{l}^{-1}\right)$. In lactating females $(\mathrm{n}=6)$ monitored longitudinally, plasma TMAO remained low for the first 3 wk p.p. Increases in AsB concentrations observed in late lactation were closely correlated (Pearson correlation $\mathrm{r}=0.96, \mathrm{p}<0.01, \mathrm{n}=6$ ) with increases in plasma insulin-like growth factor 1 (IGF1), a growth factor known to reflect nutritional status in other mammals. Two seals outfitted with time-depth recorders began regular deep diving at different times p.p. and showed corresponding differences in biomarker concentrations. Our results indicate that (1) most lactating Weddell seals at the study site ( $70 \%$ of 20 seals studied) feed after 3 to 4 wk p.p., (2) individual lactating Weddell seals may forage as early as 9 d p.p., and (3) some Weddell seals may consume little or no food throughout lactation. Dietary biomarkers provide a simple method for distinguishing feeding and fasting in freeliving marine mammals.
\end{abstract}

KEY WORDS: Foraging $\cdot$ Dietary biomarker $\cdot$ Arsenobetaine $\cdot$ Trimethylamine $N$-oxide $\cdot$ Osmolytes Lactation · Weddell seal · Marine mammal

\section{INTRODUCTION}

Large species of marine mammals commonly undergo seasonal fasts associated with migration, moulting, and reproduction (Oftedal 1993, 1997, 2000, Boyd 1998). Among phocid seals that do not enter the water during the lactation period, spatial separation of reproduction and feeding provides a unique opportunity to study the energetics of fasting lactation (Mellish et al.
1999, Mellish \& Iverson 2001) as well as hypotheses regarding parental investment (Kretzmann et al. 1993, Wilkinson \& van Aarde 2001) and the evolution of capital breeding strategies (Jönsson 1997, Boyd 2000, Crocker et al. 2001). However, in species that feed during lactation (approximately half of all phocid species; Boness \& Bowen 1996, Bowen et al. 2001b, Eisert 2003), the relative importance of 'income' vs. 'capital' (Jönsson 1997) to reproductive energetics is poorly 
understood, because food intake is difficult to detect and quantify in free-living marine mammals.

The general problem of detecting food intake in marine mammals has been addressed by equipping animals with time-depth recorders (TDRs), often in combination with additional instruments. Two-dimensional (Kooyman 1967, Hindell et al. 1991, Bengtson \& Stewart 1992, Schreer \& Testa 1996) or 3-dimensional (Harcourt et al. 2000, Mitani et al. 2003) TDRs generate dive profiles thought to indicate hunting behaviour, but provide no direct evidence of feeding (Andrews 1998). The combination of TDRs and animal-borne underwater cameras occasionally allows direct observation of foraging, as well as correlation of dive profiles to specific activities (Marshall 1998, Davis et al. 1999, Bowen et al. 2002). Unfortunately, limited storage capacity for images restricts camera observations to hours or a few days at a time, resulting in minimal coverage of biologically relevant periods such as lactation. Jaw movement sensors designed to detect mouth opening by means of electromagnetic contacts glued to the animal's jaws (Bornemann et al. 1992, Plötz et al. 2001) require precise placement of reed contacts and hence prolonged anaesthesia. Jaw opening, although suggestive of feeding, may accompany unsuccessful feeding attempts or occur in behavioural contexts other than feeding. Stomach temperature sensors detect influx of colder exogenous material to the seal's stomach, but this method is susceptible to loss of sensors due to regurgitation, false positives produced when the animal swallows ice or water, and decreasing signal strength with increasing stomach fullness (Bornemann 1994, Hedd et al. 1996, Andrews 1998). All methods that depend on extensive animal-borne instrumentation require animals to be captured prior to a study, possibly affect animal behaviour, and may be limited in scope by cost of instruments or the effort necessary to attach instruments under field conditions.

We propose to apply a novel method of detecting fasting and feeding, the dietary biomarker method, to the study of foraging in marine mammals. The dietary biomarker method is based on the same principle that is used in drug testing: appearance in body fluids of specific compounds-in this case compounds of strictly dietary origin (dietary biomarkers) represents conclusive evidence of food consumption. Suitable dietary biomarkers should occur in sufficient quantities in the diet, produce a measurable signal in the consumer, and have no sources other than diet. Biomarkers should also undergo minimal metabolism or storage and have simple kinetics to reduce the number of assumptions to be tested. Compounds that meet these criteria have been identified among organic osmolytes and osmolyte analogues found naturally in marine biota.

Organic osmolytes are small, polar molecules (polyols, amino acids, methylamines and their analogues) that contribute to the osmotic potential of cells or tissues (Baskakov et al. 1998, Lang et al. 1998) and thus protect cells against volume loss in hypertonic media (Fan et al. 1993, Lang et al. 1998) and against freezing damage (Raymond 1994, 1998, Treberg et al. 2002). Glycine betaine (Fig. 1) is a methylamine osmolyte common among plants and animals. Other osmolytes are taxon-specific (Yancey et al. 1982, Carr et al. 1996), for example marine invertebrates and fish use several osmolytes not used by mammals and vice versa (Yancey et al. 1982, Burg 1995). Taxon-specific osmolytes have a key feature that makes them ideal dietary biomarkers: unlike an organism's own osmolytes, which are often under homeorhetic control and retained even in the fasting state, 'foreign' osmolytes absorbed from the diet tend to be rapidly eliminated in urine (Ágústsson \& Strøm 1981, Lever et al. 2004) and thus produce a specific, transient signal in the consumer.

Two of several potential osmolyte biomarkers identified by our group are trimethylamine $N$-oxide (TMAO), an organic osmolyte of many marine fish and invertebrates, and arsenobetaine (AsB), an arsenic analogue of the common organic osmolyte glycine betaine (Fig. 1) that is widely distributed in marine biota. To our knowledge, these 2 compounds have not previously been measured in the blood of marine mammals, although AsB has been shown to be the predominant arsenical in tissues of marine amniotes, i.e. marine reptiles, birds, and mammals (Goessler et al. 1998b, Ebisuda et al. 2002, 2003, Kubota et al. 2002, 2003, Fujihara et al. 2003).

The Antarctic Weddell seal Leptonychotes weddellii (Phocidae) provides a suitable test case for applying the dietary biomarker method to a free-living marine mammal. The Weddell seal is predicted to fast throughout lactation based on phylogeny (Boness \& Bowen 1996), maternal body size (Boness \& Bowen 1996, Bowen et al. $2001 b)$, and greater efficiency of energy transfer in fasting lactation (Fedak \& Anderson 1982, Costa et al.

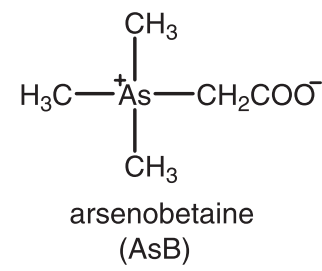<smiles>C[N+](C)(C)CC(=O)[O-]</smiles>

glycine betaine

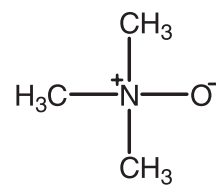

trimethylamine $\mathrm{N}$-oxide (TMAO)

Fig. 1. Chemical structures of arsenobetaine, glycine betaine, and trimethylamine $N$-oxide 
1986), yet indirect evidence from dive patterns and body mass changes (Testa et al. 1989, Hindell et al. 2002, Sato et al. 2002) and isolated direct observations (Lindsey 1937, Sato et al. 2002) indicate that some lactating females and/or nursing pups may feed. The aim of our study was to determine onset and prevalence of foraging in lactating Weddell seals and to test the dietary biomarker method in a wild population. Concentrations of AsB and TMAO were measured in lactating Weddell seals during the initial postpartum fast and at various stages during the lactation period. In a subset of seals in late lactation, plasma levels of AsB were compared with plasma levels of insulin-like growth factor 1 (IGF1), a compound known to correlate with refeeding in other mammals (see 'Discussion'). We also monitored concurrent changes in diving behaviour and plasma biomarker concentrations in 2 lactating females from mid- to late lactation.

\section{MATERIALS AND METHODS}

Study site and design. Research was conducted on lactating Weddell seal females between October and December 1998 at the Hutton Cliffs colony, McMurdo Sound, Antarctica. For the purposes of this research, lactation in Weddell seals (42 to 55 d; Lindsey 1937 , Kaufmann et al. 1975, Thomas \& DeMaster 1983) was considered to consist of 3 stages, early lactation (0 to 13 d postpartum [d p.p.]), mid-lactation (14 to $26 \mathrm{~d}$ p.p.) and late lactation ( $\geq 27 \mathrm{~d}$ p.p.). Lactation stage of study animals was ascertained by noting pup birth dates during daily patrols. Individual seals were identified by flipper tags applied by a research group led by Prof. Don Siniff, University of Minnesota, USA.

Adult females were captured by head-bagging (Stirling 1966) and blood samples were collected into heparinised containers by venipuncture from extradural or posterior flipper sites (Cline et al. 1969, Geraci 1971). Blood samples were placed on crushed ice and centrifuged to obtain plasma within $2 \mathrm{~h}$ of collection. Plasma was frozen immediately at $-28^{\circ} \mathrm{C}$ at the field camp and stored frozen until analysis. Three studies were undertaken with animals in this colony: (1) Comparison of plasma biomarker concentrations in early and late lactation: Blood samples were collected from lactating females during early (<14 d p.p., $\mathrm{n}=16)$ and late lactation (27 to 43 d p.p., $\mathrm{n}=20$ ). For this comparison, only 1 sample was used per seal. (2) Change of plasma TMAO in early and mid-lactation: Six lactating females were captured repeatedly at 2 to $6 \mathrm{~d}$ intervals. One female was monitored from 4 to $14 \mathrm{~d}$ p.p., the remaining 5 females were captured from 2 to 5 until 22 to 27 d p.p. (3) Relation of plasma biomarker concentrations to dive activity: TDRs were used to study dive behaviour in 2 lactating Weddell seals from 7 and 14 until 38 d p.p. with concurrent monitoring of plasma biomarkers. TDRs (1-channel data-loggers 'pillboxlogger', 8 bit, Driesen \& Kern) sampled pressure at $8 \mathrm{~s}$ intervals (Bornemann et al. 1998) and were provided by the Alfred-Wegener-Institut für Polar- und Meeresforschung (AWI), Bremerhaven, Germany. TDRs were attached to mats glued to the seals' dorsal pelage as previously described (Bornemann \& Plötz 1993, Bornemann et al. 1998). Seals were recaptured by head-bagging at intervals of 4 to $10 \mathrm{~d}$ for collection of samples, exchange of data loggers and retrieval of data. Dives exceeding $7 \mathrm{~m}$ recorded depth were counted manually after transfer of depth-time data into spreadsheet format (Microsoft Excel).

Experimental procedures involving Weddell seals were approved by the Lincoln University Animal Ethics Committee and conducted under a permit issued by the New Zealand Department of Conservation (28 September 1998) and Antarctica New Zealand Environmental Authorisation no. 98/11. Sample material was imported to the USA for AsB analysis under Marine Mammal Permits 834 and 7631534.

AsB analysis. AsB was analysed in Weddell seal plasma in triplicate by graphite furnace-atomic absorption spectrometry (GF-AAS) after extraction and chromatographic separation. The method presented here (Eisert 2003) was developed based on an unpublished method by Trevor Walmsley and Michael Lever (Canterbury Health Laboratories, Christchurch, New Zealand) and is similar in principle to a published procedure by Nixon \& Moyer (1992). Plasma samples were extracted with a methanol:water mixture, 9:1 v/v (Goessler et al. 1998a) followed by ion-exchange chromatography to separate quaternary arsonium compounds (AsB) from inorganic and anionic organic forms of arsenic (chemical symbol As) potentially present in samples and also to remove phosphate, which interferes with arsenic determination by GF-AAS (Welz \& Sperling 1999). Exclusion of inorganic arsenic $\left(\mathrm{H}_{3} \mathrm{AsO}_{4(\mathrm{aq})}\right.$ at equimolar concentration of $\left.\mathrm{AsB}\right)$ and of phosphate $\left(\mathrm{K}_{2} \mathrm{HPO}_{4(\mathrm{aq})}, 800 \mathrm{ppm}\right)$ was confirmed in preliminary experiments. Plasma extracts (methanol: water) were evaporated to dryness, re-suspended in a small volume of $10 \mathrm{M} \mathrm{NaOH}$, loaded on a disposable strong anion-exchange column (ICH quaternary ammonium, Alltech Associates) and eluted with distilled water. The eluate was concentrated and AsB was determined in the final sample as total arsenic by GF-AAS (Perkin-Elmer 700 graphite furnace atomic spectrophotometer with continuum source background correction, Perkin-Elmer) against AsB calibration standards (purum, Fluka Chemie, CH-9471) using a palladium/ magnesium nitrate modifier (Perkin-Elmer; Welz et al. 1988, Deaker \& Maher 1999). 
Recovery of AsB added to samples before analysis was $75 \pm 10 \%$ from seal plasma $(\mathrm{n}=4)$ and $74 \pm 0.2 \%$ from aqueous standards $(n=6)$. Results were corrected for recovery. The characteristic mass was $15.9 \mathrm{pg}$ As per 0.0044 absorbance units, and the limits of detection (LOD) and quantitation (LOQ) were $0.06 \mathrm{ppb}$ As ( $\mathrm{p}<$ 0.01 , equivalent to $1.0 \mathrm{ppb}$ As in undiluted samples) and $0.2 \mathrm{ppb}$ As (3.5 ppb As before dilution), respectively. Between- and within-assay coefficients of variation were $7.6 \%(n=3)$ and $3.8 \%$ (mean of 71 samples analysed in triplicate), respectively.

TMAO analysis. TMAO was measured in blood plasma in duplicate by high-performance liquid chromatography (HPLC) after extraction and derivatisation by alkylation with 6-methoxy 2-naphthacyl triflate (Happer et al. 2004) using a modification of the method of Lever et al. (1992) as described in Eisert (2003). Derivatised samples were analysed on a Shimadzu Class VP HPLC (Shimadzu) with a RF-10AXL fluorescence detector (Shimadzu, wavelength $\lambda_{\text {ex }} 247 \mathrm{~nm}$, $\lambda_{\text {em }} 431 \mathrm{~nm}$ ). Derivatives were separated on a strong cation exchange column (Alltech Adsorbosphere SCX, $5 \mu \mathrm{m}$, part no. 287472, Alltech Associates). The mobile phase consisted of propan-2-ol containing 3.5\% water, $4 \%$ dichloromethane $(\mathrm{v} / \mathrm{v}), 60 \mathrm{mM}$ triethanolamine and $120 \mathrm{mM}$ glycolic acid (w/v) run isocratically at $1 \mathrm{ml} \mathrm{min}^{-1}$ and $40^{\circ} \mathrm{C}$.

Recovery of TMAO added to plasma samples before analysis was $97 \pm 2 \%(\mathrm{n}=7)$. LOD and LOQ were ca. 15 and $25 \mu \mathrm{mol} \mathrm{l^{-1 }}$ TMAO, respectively. Betweenand within-assay coefficients of variation were $15.6 \%$ ( $\mathrm{n}=16$ ) and $8.2 \%$ (mean of 15 samples analysed in quadruplicate), respectively.

Due to logistical constraints, not all samples collected were analysed for both biomarkers.

Insulin-like growth factor 1 (IGF1) analysis. IGF1 in blood plasma was measured using an IGF-binding protein (IGFBP)-blocked radioimmunoassay (RIA; Breier et al. 1991, Blum \& Breier 1994). Recovery of unlabelled IGF1 added to samples before analysis was $96 \pm 7.6 \%$ ( $\mathrm{n}=14$ ). The $\mathrm{ED}_{50}$ was $0.1 \mathrm{ng}$ per tube, the detection limit was $0.7 \mathrm{ng} \mathrm{ml}^{-1}$ and the between- and within-assay coefficients of variation were 10.1 and $5.0 \%$, respectively. As degree of crossreactivity between Weddell seal IGF1 and the polyclonal antibody is unknown, IGF1 results represent immunoreactive IGF1 concentrations.

Calculation of fasting limits of biomarkers. Weddell seals reportedly remain with their pups for at least the first week after giving birth, providing a minimal estimate for the duration of the postpartum fast (Kaufmann et al. 1975). We assumed that lactating Weddell seals would consume no food during the first week p.p. Plasma concentrations of AsB and TMAO measured at this time were used to estimate 1-tailed 95\% upper confidence limits from the $t$-distribution and standard deviations (Sokal \& Rohlf 1969). Plasma biomarker concentrations above these limits (fasting limits) were considered to represent feeding, allowing animals to be classified as feeding or fasting.

Statistical analysis. Unless stated otherwise, results are given as mean \pm SEM. Mean values were compared using Student's $t$-test for normally distributed data. For data that were not normally distributed, median values were compared using the Mann-Whitney rank sum test. Linear correlations were evaluated using Pearson rank correlation or Spearman rank correlation as appropriate (Sheskin 2000). Linear regression statistics were computed using the Deming regression procedure (Linnet 1998) with or without logarithmic transformation of raw data.

\section{RESULTS}

\section{Fasting levels of biomarkers}

Plasma concentrations of biomarkers measured in lactating Weddell seals during the first week of lactation ( $\leq 7$ d p.p.) were (mean \pm SD) $5.7 \pm 2$ ppb AsB-As, $\mathrm{n}=3$, and $45 \pm 20 \mu \mathrm{mol} \mathrm{l}^{-1}$ TMAO, $\mathrm{n}=10$. Calculated fasting limits were $11 \mathrm{ppb}$ AsB-As and $81 \mu \mathrm{mol} \mathrm{l^{-1 }}$ TMAO. Seals with plasma concentrations exceeding these limits were considered to be feeding.

\section{Comparison of plasma biomarker concentrations in early and late lactation}

Biomarker concentrations were compared between 2 groups of lactating Weddell seals, early lactation (<14 d p.p.) and late lactation ( $\geq 27$ d p.p.) as shown in Table 1. Mean plasma concentrations of both biomarkers were approximately 10 -fold higher in late compared to early lactation (Table 1), and differences in median biomarker plasma concentrations were significant for both AsB (Mann-Whitney rank sum test: $\mathrm{p}=0.02$ ) and TMAO (Mann-Whitney rank sum test: $\mathrm{p}=0.03)$.

In early lactation after the first week p.p. (8 to $13 \mathrm{~d}$ p.p.), plasma biomarker concentrations in excess of the fasting limits were observed in 2 out of 5 lactating females, i.e. in 1 of 4 animals for TMAO (Seal M1125, $321 \mu_{\text {mol l }}^{-1}$ TMAO, 9 d p.p.) and in 1 of 3 animals for AsB (Seal 821, 13 ppb AsB-As, $30 \mu \mathrm{mol} \mathrm{l^{-1 }}$ TMAO, 9 d p.p.). Seal M1125 was captured ca. 10 min after returning from a dive but unfortunately, only TMAO was measured. In Seal 821, the combination of elevated AsB and low TMAO plasma concentrations suggests that feeding took place at least a day prior to sample collection. In late lactation, there was good 
Table 1. Leptonychotes weddellii. Biomarker concentrations and estimated prevalence of feeding by Weddell seals in early and late lactation. Numbers in square brackets indicate median concentrations of arsenobetaine (AsB) and trimethylamine $N$-oxide (TMAO)

\begin{tabular}{|c|c|c|}
\hline & Early lactation & Late lactation \\
\hline \multicolumn{3}{|c|}{ Number of seals studied } \\
\hline AsB & 6 & 20 \\
\hline TMAO & 14 & 15 \\
\hline \multicolumn{3}{|l|}{ Days postpartum } \\
\hline AsB & $7 \pm 1$ & $34 \pm 1$ \\
\hline TMAO & $6 \pm 1$ & $35 \pm 1$ \\
\hline \multicolumn{3}{|c|}{ Plasma biomarker concentrations } \\
\hline AsB (ppb As) & $5.5 \pm 2[4.8]$ & $57 \pm 17[25]$ \\
\hline TMAO $\left(\mu \mathrm{mol} \mathrm{l} l^{-1}\right)$ & $66 \pm 20[49]$ & $685 \pm 199[380]$ \\
\hline \multicolumn{3}{|c|}{$\begin{array}{l}\text { Proportion of seals with biomarker concentration > } \\
\text { fasting limits }\end{array}$} \\
\hline $\mathrm{AsB}$ & $17 \%(1$ of 6$)$ & $70 \%(14$ of 20$)$ \\
\hline TMAO & $7 \%(1$ of 14$)$ & $73 \%(11$ of 15$)$ \\
\hline
\end{tabular}

agreement between biomarkers with regard to the proportion of lactating Weddell seals sampled that had values exceeding fasting limits, with 14 of 20 of seals $(70 \%)$ above fasting limits for AsB and 11 of 15 of seals (73\%) above fasting limits for TMAO.

Decline of plasma AsB concentrations during early lactation was estimated based on cross-sectional samples below the fasting limit $(n=5)$. Decline of arsenobetaine in early lactation was monoexponential (Fig. 2A inset) and the decay constant was estimated by Deming linear regression analysis of the $\log _{e}$ of plasma AsB-As values $[\ln (y)]$ versus d p.p. $(x)$ :

$$
\ln (y)=-0.33 x+3.39, \mathrm{r}=-0.94, \mathrm{p}<0.05
$$

In exponential form:

$$
y(x)=30 \mathrm{e}^{-0.33 x}
$$

By contrast, there was no significant change in plasma TMAO concentrations during early lactation (Fig. 2B inset).

\section{Change of plasma TMAO in early and mid-lactation}

Plasma TMAO concentrations were monitored longitudinally in 6 lactating females (Fig. 3) Plasma TMAO concentrations remained below the fasting limit for TMAO $\left(81 \mu \mathrm{mol} \mathrm{l}^{-1}\right)$ in all animals during the entire study period, 4 to $14 \mathrm{~d}$ p.p. for 1 female and $3 \pm 1$ to $25 \pm 1$ d p.p. for the remaining 5 seals. No consistent pattern of change in plasma TMAO concentrations was observed in this group.
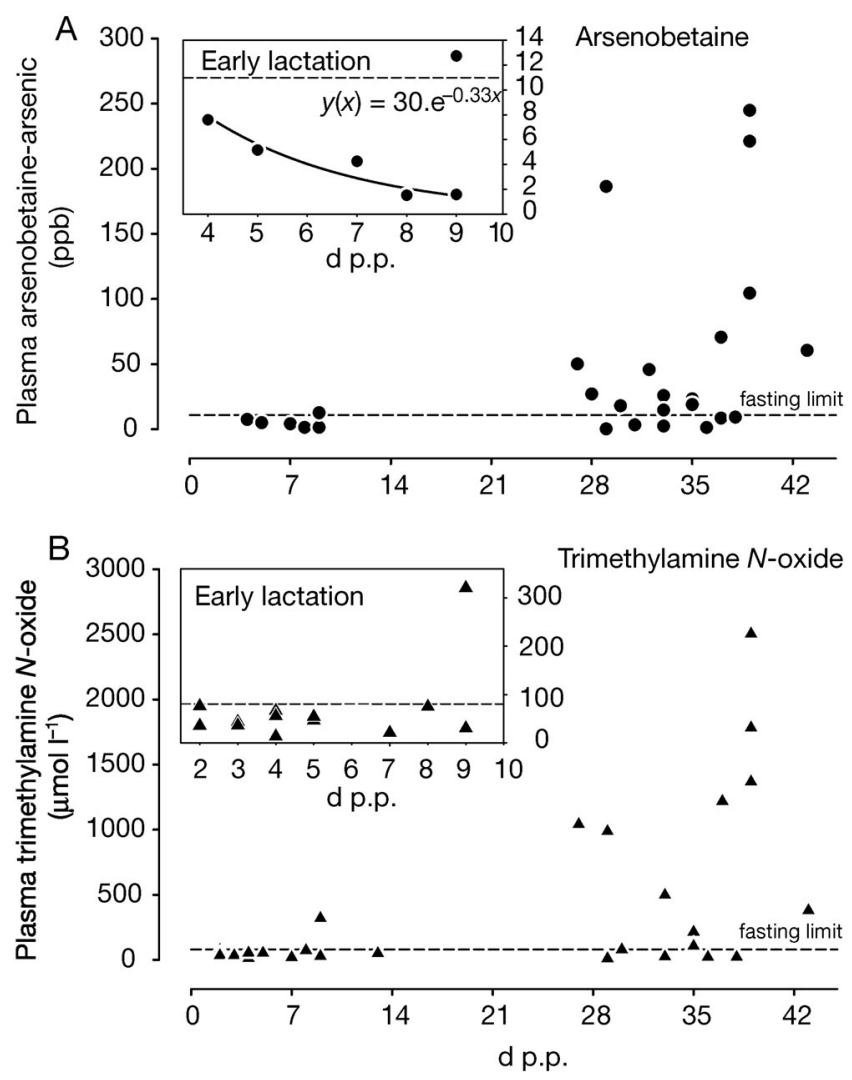

Fig. 2. Leptonychotes weddellii. Plasma concentrations of (A) arsenobetaine and (B) trimethylamine $N$-oxide in Weddell seals during early and late lactation. Data from early lactation are shown in expanded form in insets. Exponential decline of arsenobetaine in early lactation was estimated by Deming linear regression analysis after $\log _{\mathrm{e}}$ transformation $(\mathrm{r}=$ $-0.94, \mathrm{p}<0.05)$. For calculation of fasting limits $(---)$ see 'Materials and methods'

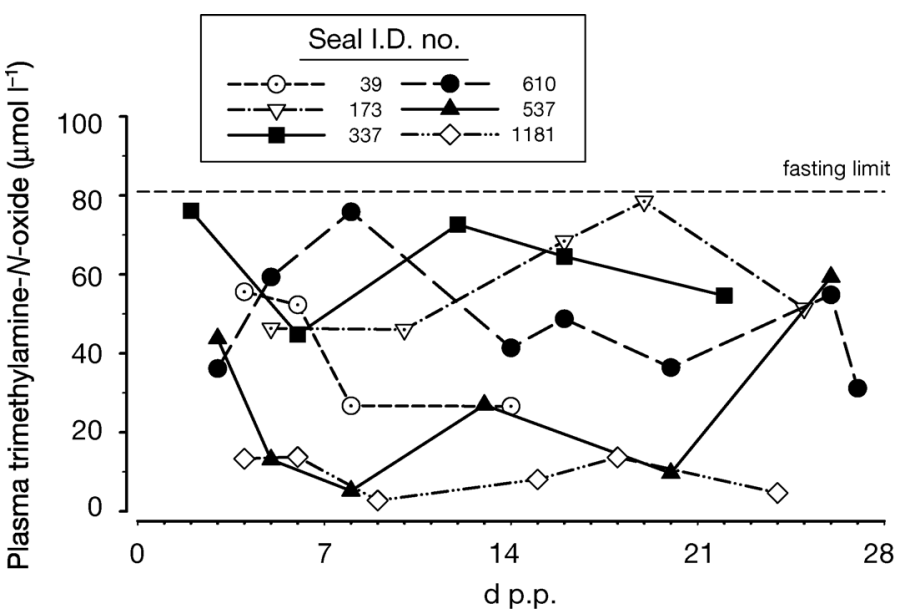

Fig. 3. Leptonychotes weddelli. Changes in plasma trimethylamine $\mathrm{N}$-oxide concentration in lactating Weddell seals sampled repeatedly during early and mid-lactation. For calculation of the fasting limit (---) see 'Materials and methods' 


\section{Relationship between plasma biomarker concentrations and dive activity}

Diving activity and plasma biomarker concentrations were monitored concurrently in 2 lactating females (seals with I.D. tags orange 318 and red 572, referred to as 318 and 572; Fig. 4).

In Seal 318 (Fig. 4A), plasma concentrations of AsBAs declined approximately linearly from $5 \mathrm{ppb}$ at $7 \mathrm{~d}$ p.p. to below the LOD $(<1 \mathrm{ppb})$ at $14 \mathrm{~d}$ p.p., and remained below 1 ppb until 23 d p.p. Between 23 and $27 \mathrm{~d}$ p.p., plasma concentrations of AsB-As increased above the fasting limit, from $<1 \mathrm{ppb}$ at $23 \mathrm{~d}$ p.p. to 19 ppb at 27 d p.p., and plasma AsB-As was also elevated at $38 \mathrm{~d}$ p.p. with $25 \mathrm{ppb}$. Changes in plasma concentrations of TMAO were similar to those observed for plasma AsB-As, with the difference that TMAO was low $(<25 \mu \mathrm{M})$ at the beginning of the study at 7 d p.p. Seal 318 made few, shallow dives

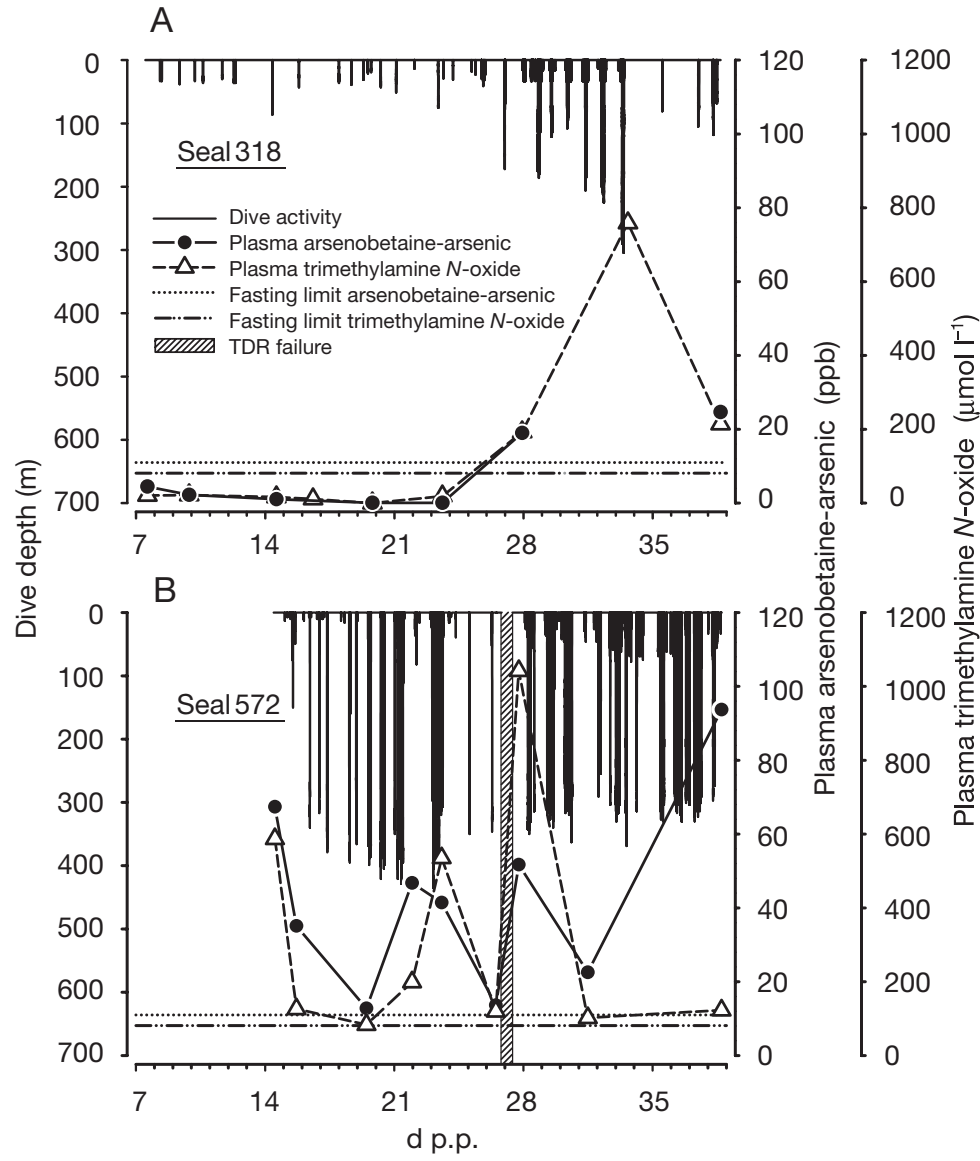

Fig. 4. Leptonychotes weddellii. Comparison of dive activity with plasma concentrations of biomarkers in 2 lactating Weddell seals, (A) Seal 318 and (B) Seal 572. Vertical solid lines indicate dive activity as depth below surface. Fasting limits for arsenobetaine-arsenic and trimethylamine $\mathrm{N}$-oxide were calculated as described in 'Materials and methods'. Loss of data due to TDR failure in Seal 572 is indicated by cross-hatching (depth $<50 \mathrm{~m}$ ) as early as 8 d p.p. (Fig. 4A). Dives exceeded 50 m depth at 14,21,23, 26 d p.p. and afterwards on most days until the end of the study period (38 d p.p.). At 28 d p.p., the frequency of all dives and those exceeding $50 \mathrm{~m}$ depth increased markedly and remained high until the end of the study period, $38 \mathrm{~d}$ p.p. (all dives: 7 to $27 \mathrm{~d}$ p.p., $3 \pm 1 \mathrm{~d}^{-1}$; 28 to $38 \mathrm{~d}$ p.p., $\left.22 \pm 7 \mathrm{~d}^{-1}\right)$. The increase in dive frequency occurred concurrently with the increase in plasma biomarker concentrations (Fig. 4A). Overall median dive depth in Seal 318 was $31 \mathrm{~m}$ and maximum depth measured was $304 \mathrm{~m}$.

Seal 572 (Fig. 4B) was studied for a shorter period (14 to $38 \mathrm{~d}$ p.p.). Biomarker data and dive records differ noticeably from those of Seal 318. When compared with Seal 318 over the period 14 to 38 d p.p. (Fig. 4), Seal 572 had a greater number of dives per day (median number of dives: Seal 318, $2 \mathrm{~d}^{-1}$; Seal 572, $16 \mathrm{~d}^{-1}$; Mann-Whitney rank sum test, $\mathrm{p}=0.03$ ) and a greater proportion of dives exceeded $50 \mathrm{~m}$ (dives below $50 \mathrm{~m}$ as a percentage of total number of dives per day: Seal 318, $25 \pm$ $7 \%$; Seal 572, $44 \pm 5 \%$; Student's $t$-test, $\mathrm{p}=0.04)$. In Seal 572, concentrations of AsB-As and TMAO were highly variable and elevated above fasting limits throughout the study period (AsB-As, range 12 to $92 \mathrm{ppb}$, mean $43 \pm 9 \mathrm{ppb}$; TMAO, range 83 to $1040 \mu \mathrm{mol} \mathrm{l}{ }^{-1}$, mean $324 \pm 110 \mu \mathrm{mol}$ $\mathrm{l}^{-1}$ ). Increase and decrease of AsB-As and TMAO were approximately synchronous although concentrations of the 2 biomarkers diverged at 21 and 38 d p.p. Observed decreases in biomarker concentrations appeared to be unrelated to preceding changes in dive activity, with the exception of a period of low activity from 25 to $28 \mathrm{~d}$ p.p. that was followed by a decrease in plasma concentrations of AsB-As and TMAO. Due to TDR failure, no records exist for the time between 19:00 h 26 d p.p. to 09:00 h 27 d p.p. (Fig. 4B). Overall median dive depth in Seal 572 was $134 \mathrm{~m}$ and maximum dive depth measured was $435 \mathrm{~m}$.

\section{AsB and IGF1 in late lactation}

There was a strong positive linear correlation between plasma concentrations of AsB and IGF1 (Pearson correlation $\mathrm{r}=0.96, \mathrm{p}<$ 0.01 , Fig. 5) in a subset of Weddell seal females in late lactation ( $\mathrm{n}=6$, mean $35 \pm$ $2 \mathrm{~d}$ p.p., range 31 to $43 \mathrm{~d}$ p.p.). There was no significant relationship between either 


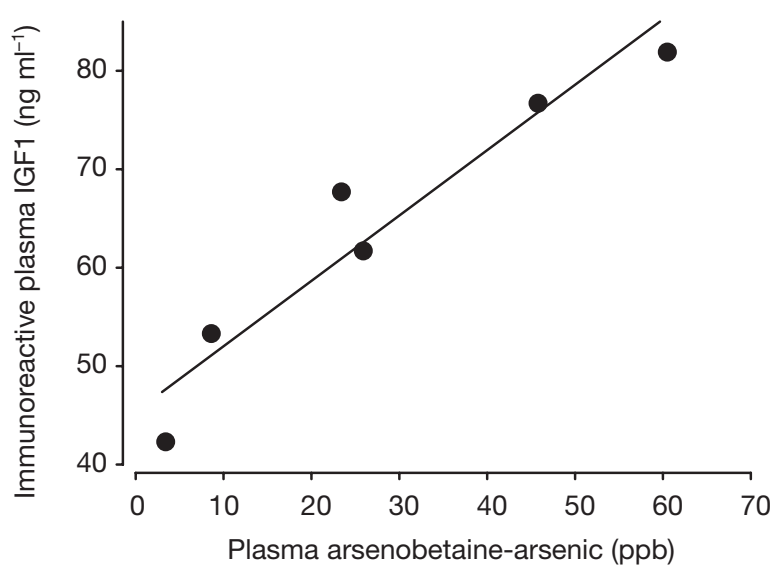

Fig. 5. Leptonychotes weddellii. Relationship between plasma concentrations of insulin-like growth factor 1 (IGF1, $y$-axis) and arsenobetaine ( $x$-axis) in Weddell seals during late lactation, range 31 to $43 \mathrm{~d}$ postpartum. By Deming linear regression analysis: $y(x)=0.664 x+45.4, \mathrm{r}^{2}=0.91$, $\mathrm{p}<0.01, \mathrm{n}=6$

parameter and time postpartum (Pearson correlation, $\mathrm{p}=0.26[$ AsB, IGF1]; Spearman rank correlation, $\mathrm{p}=$ $0.42[\mathrm{AsB}]$ and $\mathrm{p}=0.36$ [IGF1]).

\section{Correlation of biomarkers AsB and TMAO}

There was a strong positive linear relationship between plasma concentrations of AsB and TMAO concentrations after logarithmic transformation (Pearson correlation $\mathrm{r}=0.88, \mathrm{p}<0.0001, \mathrm{n}=21$, including all samples analysed for both biomarkers irrespective of lactation stage). The correlation is marginally improved (Pearson $\mathrm{r}=0.90, \mathrm{p}<0.0001, \mathrm{n}=14$ ) if pairs of values below the limits of quantitation for either analyte are excluded (Fig. 6). The latter is consistent with faster elimination of TMAO from the plasma compartment, which would be predicted to cause loss of correlation between AsB and TMAO at low concentrations. This is a possible explanation for the presence of elevated AsB (13 ppb As) and low TMAO $\left(30 \mu \mathrm{mol} \mathrm{l}^{-1}\right)$ concentrations in Seal 821 at $9 \mathrm{~d}$ p.p. (see above).

\section{DISCUSSION}

This study presents the use of marine osmolytes and their analogues to detect recent feeding in free-living marine mammals. Applied to the Weddell seal, this dietary biomarker method provides definitive information on the onset and prevalence of foraging in a population of lactating Weddell seals.

\section{Characteristics of the dietary biomarkers used}

The biomarkers used in this study, AsB and TMAO, are common constituents of marine organisms (Yancey et al. 1982, Van Waarde 1988, Cullen \& Reimer 1989, Edmonds \& Francesconi 1993, Carr et al. 1996) but are not synthesised or stored to a significant degree by mammals (Vahter et al. 1983, Al-Waiz et al. 1987a,b, 1992, Cullen \& Reimer 1989, Brown et al. 1990, Mitchell et al. 1997). AsB occurs in marine organisms from zooplankton to teleost fish and is the dominant quaternary arsonium compound, and in most cases the dominant form of arsenic, in almost all marine fish and invertebrates studied (Cullen \& Reimer 1989, Shibata et al. 1992, Shibata et al. 1996, Francesconi 2003; Table 2 and references therein). Arsenic compounds found in marine organisms include arsenosugars, arsenolipids, inorganic and anionic organic compounds (arsenate, methylarsonate, dimethylarsonite), and quaternary arsonium compounds other than AsB (trimethylarsonium oxide and the tetramethylarsonium ion). Replacement of AsB as the dominant arsenical by another quaternary arsonium compound, trimethylarsonium oxide, has only been reported for a single species of fish (Edmonds et al. 1997). AsB is retained by marine fish and invertebrates (Cullen \& Reimer 1989, Francesconi et al. 1999) but probably in insufficient concentrations to be effective as an osmolyte. Unlike

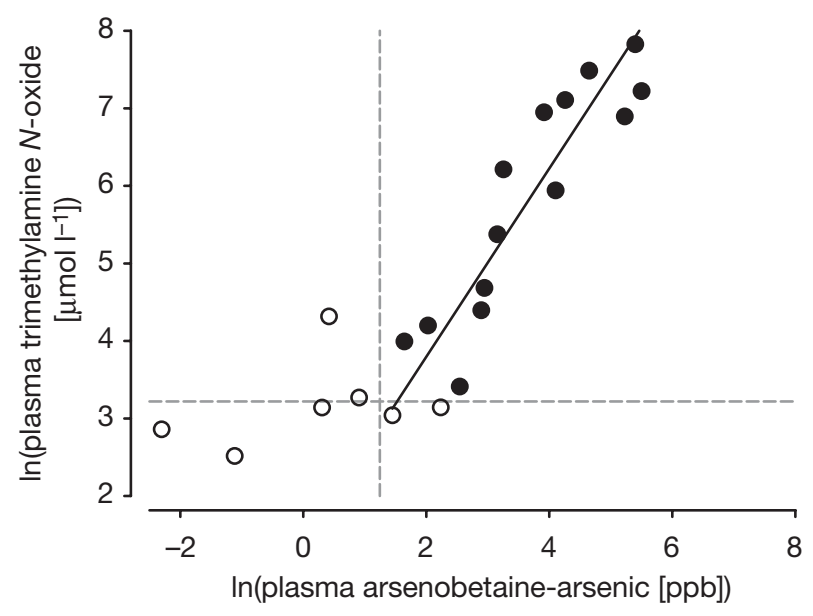

Fig. 6. Leptonychotes weddellii. Relationship between plasma concentrations of arsenobetaine ( $x$-axis) and trimethylamine $\mathrm{N}$-oxide ( $\mathrm{y}$-axis) in lactating Weddell seals. Limits of quantitation (LOQ) are indicated by dashed lines. (O): values below the LOQ of either method; $(\bullet)$ : values above the LOQ. Results of Pearson correlation for all values after $\log _{\mathrm{e}}$ transformation are $\mathrm{r}=0.88, \mathrm{p}<0.0001, \mathrm{n}=21$. Linear regression of pairs of values above the LOQ of either method (Deming linear regression analysis: $\ln (y)=1.21 \ln (x)$ +1.37 ) is shown as a solid line (Pearson correlation $r=0.90$, $\mathrm{p}<0.0001, \mathrm{n}=14)$ 
Table 2. Concentration of total arsenic (As), arsenobetaine (AsB) and quaternary arsonium compounds (QACs) in marine fish and invertebrates. $\mathrm{n} / \mathrm{r}$ : not recorded; $\mathrm{n} / \mathrm{m}$ : not measured

\begin{tabular}{|c|c|c|c|c|c|c|c|c|}
\hline Common name & Species & Tissue & Origin & $\begin{array}{l}\text { Total As } \\
\text { (ppm) }\end{array}$ & $\begin{array}{l}\text { AsB-As } \\
\text { (ppm) }\end{array}$ & $\begin{array}{c}\text { AsB } \\
(\% \text { of tot }\end{array}$ & $\begin{array}{c}\text { QAC } \\
\text { tal As) }\end{array}$ & Source \\
\hline \multicolumn{9}{|l|}{ Cnidarians } \\
\hline Box jellyfish & Carybdea rastonii & Whole animal & Japan & 0.135 & $\mathrm{n} / \mathrm{m}$ & \multicolumn{2}{|c|}{ 'Major'a n/m } & Hanaoka et al. (1999) \\
\hline \multicolumn{9}{|c|}{ Molluscs } \\
\hline Phoenician neptune & Neptunea lyrata phoenicea & Soft tissue & $\mathrm{n} / \mathrm{r}$ & 3.5 & 1.1 & 32 & $\mathrm{n} / \mathrm{m}$ & Cullen \& Reimer (1989) \\
\hline Saul's triton & Charonia sauliae & Muscle & $\mathrm{n} / \mathrm{r}$ & 117 & 67 & 58 & $\mathrm{n} / \mathrm{m}$ & Cullen \& Reimer (1989) \\
\hline Roe's abalone & Haliotis roei & Foot muscle & Australia & 1 & 0.9 & 90 & 91 & Edmonds et al. (1997) \\
\hline Blue mussel & Mytilus edulis & Soft tissues & W Australia & $19.1^{\mathrm{b}}$ & $16.6^{\mathrm{b}}$ & 87 & $\mathrm{n} / \mathrm{m}$ & Francesconi et al. (1999) \\
\hline Squid & $\mathrm{n} / \mathrm{r}$ & Edible parts & Spain & 1.6 & 1.3 & 56 & 56 & Súñer et al. (2002) \\
\hline $\begin{array}{l}\text { North-Pacific } \\
\text { giant octopus }\end{array}$ & $\begin{array}{l}\text { Paroctopus dofleini } \\
\text { (Enteroctopus dofleini) }\end{array}$ & Muscle & $\mathrm{n} / \mathrm{r}$ & 49 & $\mathrm{n} / \mathrm{m}$ & $>90$ & $\mathrm{n} / \mathrm{m}$ & Cullen \& Reimer (1989) \\
\hline \multicolumn{9}{|l|}{ Crustaceans } \\
\hline Antarctic krill & Euphausia superba & $\mathrm{n} / \mathrm{r}$ & $\mathrm{n} / \mathrm{r}$ & $\mathrm{n} / \mathrm{m}$ & $\mathrm{n} / \mathrm{m}$ & 60 & $\mathrm{n} / \mathrm{m}$ & Edmonds et al. (1997) \\
\hline King prawn & Penaeus latisulcatus & Tail muscle & Australia & $10-17$ & $9.5-16$ & 95 & $\mathrm{n} / \mathrm{m}$ & $\begin{array}{l}\text { Francesconi \& Edmonds } \\
\text { (1987) }\end{array}$ \\
\hline Red crab & Chionoecetes opilio & Soft tissue & Sea of Japan & 3.5 & 3.2 & 90 & $\mathrm{n} / \mathrm{m}$ & Matsuto et al. (1986) \\
\hline \multicolumn{9}{|c|}{ Cartilaginous fish } \\
\hline Dogfish (DORM-2) ${ }^{\mathrm{c}}$ & Squalus acanthias & Muscle & Canada & $17.7^{\mathrm{b}}$ & $16.0^{\mathrm{b}}$ & 90 & 92 & Goessler et al. (1998a) \\
\hline Starspotted shark & Mustelus manazo & Muscle & $\mathrm{n} / \mathrm{r}$ & 17.3 & 16.9 & 98 & $\mathrm{n} / \mathrm{m}$ & Hanaoka et al. (1987) \\
\hline \multicolumn{9}{|l|}{ Teleost fish } \\
\hline Silver drummer & Kyphosus sydneyanus & Muscle & Australia & 1.0 & 0 & 0 & $98^{\mathrm{d}}$ & Edmonds et al. (1997) \\
\hline Tailor (bluefish) & Pomatomus saltatrix & Muscle & Australia & $2.8^{\mathrm{b}}$ & $2.6^{\mathrm{b}}$ & 94 & 94 & Kirby \& Maher (2002) \\
\hline Tuna (CRM 627) ${ }^{\mathrm{C}}$ & $\mathrm{n} / \mathrm{r}$ & Muscle & $\mathrm{n} / \mathrm{r}$ & $4.8^{\mathrm{b}}$ & $4.1^{\mathrm{b}}$ & 85 & 85 & Nakazato et al. (2000) \\
\hline European plaice ${ }^{c}$ & Pleuronectes platessa & Muscle & North Sea & $43.2^{\mathrm{b}}$ & $40.3^{\mathrm{b}}$ & 95 & 95 & $\begin{array}{l}\text { Larsen et al. (1997), } \\
\text { Súñer et al. (2000) }\end{array}$ \\
\hline European anchovy & Engraulis encrasicolus & Edible parts & Spain & 3.2 & 2.7 & 82 & 85 & Súñer et al. (2002) \\
\hline European pilchard & Sardina pilchardus & Edible parts & Spain & 4.3 & 3.4 & 70 & 70 & Súñer et al. (2002) \\
\hline European hake & Merluccius merluccius & Edible parts & Spain & 2.0 & 1.8 & 85 & 86 & Súñer et al. (2002) \\
\hline Megrim & Lepidorhombus sp. & Edible parts & Spain & 3.3 & 2.8 & 85 & 85 & Súñer et al. (2002) \\
\hline
\end{tabular}

other forms of arsenic, AsB has very low toxicity (Cannon et al. 1983, Shibata et al. 1992, Sakurai \& Fujiwara 2001), presumably because vertebrates are incapable of breaking down AsB (Vahter et al. 1983, Edmonds \& Francesconi 1988, Cullen \& Reimer 1989, Yoshida et al. 1998). Despite the structural similarity between AsB and glycine betaine (Fig. 1), AsB is not metabolised by the mammalian enzyme betaine-homocysteine transferase (BHMT) that demethylates glycine betaine (Lee et al. 2004).

TMAO is an important osmolyte in marine fish and invertebrates and is typically present in tissues in remarkably high concentrations of 0.2 to $1.5 \%$ by wet mass (Yancey \& Somero 1980, Yancey \& Siebenaller 1999; Table 3). In addition to its role in osmoregulation, TMAO is thought to stabilise enzymes of deepsea animals against pressure-induced denaturation (Kelly \& Yancey 1999, Yancey \& Siebenaller 1999), contribute to buoyancy in cartilaginous fish (Withers et al. 1994) and act as an antifreeze in teleosts (Raymond 1994, 1998, Raymond \& de Vries 1998, Treberg et al. 2002).
In mammals, TMAO and AsB ingested with food are absorbed rapidly and completely (Vahter et al. 1983, Al-Waiz et al. 1987b) and are excreted unchanged via urine (Vahter et al. 1983, Al-Waiz et al. 1987b, Brown et al. 1990, Svensson et al. 1994, Vahter 1994, Mitchell et al. 1997, Yoshida et al. 1998), with no demonstrable retention of TMAO in body tissues (Norris \& Benoit 1945, Smith et al. 1994). TMAO ingested with food is absorbed as trimethylamine from the intestinal tract after reduction by gut bacteria and re-oxidised by the liver to TMAO (Al-Waiz et al. 1987a). Low levels of TMAO present in body fluids in the absence of seafood consumption (Smith et al. 1994, Svensson et al. 1994, Lundh et al. 1995) are likely derived from breakdown of other trimethyl compounds (e.g. choline, carnitine and glycine betaine) by gut bacteria (Holmes et al. 1997). Marine foods are apparently the only significant source of elevated concentrations of TMAO in plasma and urine unless alternative precursors are administered in pharmacologic doses (Zeisel et al. 1989, Zhang et al. 1999). Following oral administration of trimethylamine in rats, plasma TMAO concentrations peaked at 
ca. $1 \mathrm{~h}$ and decreased monoexponentially with an approximate half-life of 2 to $3 \mathrm{~h}$ (Smith et al. 1994, Nnane \& Damani 2001). In studies with radioactively labelled TMAO, 95\% of an oral dose was excreted from the body within $24 \mathrm{~h}$ in rats (Mitchell et al. 1997) and humans (Al-Waiz et al. 1987b). In humans, the maximum rate of excretion of TMAO occurs at 3 to $6 \mathrm{~h}$ after administration (Al-Waiz et al. 1987b).

AsB is less rapidly excreted than TMAO. A fraction of plasma AsB is thought to enter cells due to its structural similarity to glycine betaine (Vahter et al. 1983, Randall et al. 1996, Fujihara et al. 2003), and this sequestration decreases the rate of elimination of ingested AsB. However, unlike inorganic arsenic that binds to plasma and tissue proteins (Zhang et al. 1998, Benramdane et al. 1999, Hindmarsh 2000), exchange of AsB with intracellular pools of glycine betaine is reversible and AsB is progressively eliminated from the body. Most of a dose of ${ }^{73}$ As-labelled AsB administered to rabbits $(75 \%)$ and to rats and mice (99\%) was eliminated from the body in $3 \mathrm{~d}$ (Vahter et al. 1983). In humans, less than $1 \%$ of a dose of AsB was retained in the body after $24 \mathrm{~d}$ (Brown et al. 1990). Following fish consumption, plasma AsB concentrations in humans peaked at ca. $2 \mathrm{~h}$ after the meal and declined in 2 distinct phases with respective half-life values of ca. 7 to $12 \mathrm{~h}$ and ca. $63 \mathrm{~h}$ (Lehmann et al. 2001).

In amniotes, AsB and TMAO are of dietary origin and elevated levels of these markers in body fluids indicate recent ingestion of food of marine origin. Regular intake of marine fish and invertebrates results in high concentrations of AsB in tissues (Ebisuda et al. 2002, Kubota et al. 2002, 2003, Fujihara et al. 2003) and of both AsB and TMAO in plasma and urine (Mohri et al. 1990, Svensson et al. 1994, Lehmann et al. 2001). In the postabsorptive state, AsB and TMAO are gradually eliminated from the body, with TMAO falling to a low baseline within 1 to $2 \mathrm{~d}$ and AsB disappearing completely within days to weeks unless replenished by dietary intake.

\section{Application of the biomarker method to Weddell seals}

Weddell seals were previously thought to consume little or no food during lactation (Oftedal et al. 1987, Tedman \& Green 1987). More recently, it has been suggested that lactating Weddell seals commence feeding after an initial postpartum fast (Testa et al.

Table 3. Concentration of trimethylamine $N$-oxide (TMAO) in marine fish and invertebrates. n/r: not recorded

\begin{tabular}{|c|c|c|c|c|c|c|}
\hline Common name & Species & Tissue & Origin & \multicolumn{2}{|c|}{$\begin{array}{c}\text { TMAO } \\
\left.(\mathrm{mmol} \mathrm{kg})^{-1}\right)^{\mathrm{a}, \mathrm{b}}(\%)^{\mathrm{c}}\end{array}$} & Source \\
\hline \multicolumn{7}{|l|}{ Crustaceans } \\
\hline Antarctic krill & Euphausia superba & Muscle & $\mathrm{n} / \mathrm{r}$ & 30 & 0.22 & Carr et al. (1996) \\
\hline Dock shrimp & Pandalus danae & Muscle & North Pacific & 76 & 0.57 & Kelly \& Yancey (1999) \\
\hline Blue crab & Callinectes sapidus & Muscle & Florida & 20 & 0.15 & Carr et al. (1996) \\
\hline Tanner crab & Chionoecetes bairdi & Muscle & North Pacific & 22 & 0.17 & Kelly \& Yancey (1999) \\
\hline \multicolumn{7}{|l|}{ Molluscs } \\
\hline Antarctic pteropod & Clione antarctica & $\mathrm{n} / \mathrm{r}$ & Antarctica & 112 & 0.84 & Seibel \& Walsh (2002) \\
\hline American oyster & $\begin{array}{l}\text { Ostrea virginica } \\
\text { (Crassostrea virginica) }\end{array}$ & Mantle fluid & $\mathrm{n} / \mathrm{r}$ & 240 & 1.8 & Hatton \& Gibb (1999) \\
\hline Pacific razor clam & Siliqua patula & Soft tissue & $\mathrm{n} / \mathrm{r}$ & 15 & 0.11 & Carr et al. (1996) \\
\hline Market squid & Loligo opalescens & Mantle & North Pacific & 48 & 0.36 & Kelly \& Yancey (1999) \\
\hline $\begin{array}{l}\text { Argentine shortfin } \\
\text { squid }\end{array}$ & Illex argentinus & Mantle & $\mathrm{n} / \mathrm{r}$ & 55 & 0.41 & Carr et al. (1996) \\
\hline Common octopus & Octopus vulgaris & Mantle & $\mathrm{n} / \mathrm{r}$ & 8.5 & 0.06 & Seibel \& Walsh (2002) \\
\hline \multicolumn{7}{|l|}{ Cartilaginous fish } \\
\hline Greenland shark & Somniosus microcephalus & Frozen flesh & $\mathrm{n} / \mathrm{r}$ & $140-173$ & $1.1-1.3$ & Anthoni et al. (1991) \\
\hline Shovelnosed ray & Aptychotremata vincentiana & Muscle & Australia & 162 & 1.2 & Withers et al. (1994) \\
\hline \multicolumn{7}{|l|}{ Teleost fish } \\
\hline Saffron cod & Eleginus gracilis & Muscle & Alaska & 76 & 0.57 & Raymond (1998) \\
\hline Pacific cod & Gadus macrocephalus & Muscle & North Pacific & 46 & 0.35 & Kelly \& Yancey (1999) \\
\hline Ocean pout & Macrozoarces americanus & Muscle & Canada & 38 & 0.28 & Raymond (1998) \\
\hline Pacific herring & Clupea harengus pallasi & Muscle & Alaska & 48 & 0.36 & Raymond (1998) \\
\hline Starry flounder & Platichthys stellatus & Muscle & Alaska & 27 & 0.20 & Raymond (1998) \\
\hline Antarctic toothfish & Dissostichus mawsoni & Muscle & McMurdo Sound & 154 & 1.2 & Raymond \& de Vries (1998) \\
\hline Antarctic dragonfish & Gymnodraco acuticeps & Muscle $\mathrm{N}$ & McMurdo Sound & d 148 & 1.1 & Raymond \& de Vries (1998) \\
\hline \multicolumn{7}{|c|}{$\begin{array}{l}{ }^{a} \text { Units are mmol } \mathrm{l}^{-1} \text { for liquids } \\
{ }^{\mathrm{b}} \text { For comparison, the concentration of TMAO in seawater is } 3.2 \text { to } 64 \mathrm{nmol} \mathrm{l}^{-1} \text { (Hatton \& Gibb 1999) } \\
{ }^{\mathrm{c} M a s s} \% \text { by wet weight }\end{array}$} \\
\hline
\end{tabular}


1989, Hindell et al. 2002, Sato et al. 2002), but the evidence for feeding has been mostly indirect, such as changes in dive activity (Testa et al. 1989, Hindell et al. 1999, Sato et al. 2002) and lowered rates of maternal mass loss both in absolute terms (Hill 1987) and relative to pup mass gain (Testa et al. 1989). Incidents of feeding by lactating Weddell seals have been recorded with animal-borne cameras (Sato et al. 2002), but observations are too few $(<2 \%$ of recorded images in Sato et al. 2002 showed actions consistent with food intake) to assess the prevalence of feeding in lactating Weddell seals.

Presently, the application of the biomarker method relies on the assumption that the kinetics of uptake and excretion of AsB and TMAO in Weddell seals are similar to those observed in other mammals (see above). Changes in plasma biomarker concentrations observed during the first week p.p., when Weddell seals remain with their pups and fast (Kaufmann et al. 1975), support this assumption. Between 4 and 9 d p.p., plasma AsB concentrations declined exponentially (Fig. 2A inset) as AsB ingested prior to parturition was gradually eliminated. A tentative estimate of the halflife of AsB in Weddell seals based on these crosssectional data is ca. $50 \pm 7 \mathrm{~h}$, close to the estimate of $63 \mathrm{~h}$ in humans (Lehmann et al. 2001). At this rate of decline, plasma AsB would be expected to fall below the detection limit of $1 \mathrm{ppb}$ at about 1 to 2 wk p.p., as seen in Seal 318 (Fig. 4A). In contrast to AsB, there was no consistent decrease in plasma TMAO concentrations with time between 2 and 7 d p.p., either in cross-sectional data (Fig. 2B inset) or in seals sampled repeatedly (Fig. 3). The most likely explanation is that due to the presumably shorter half-life of TMAO in Weddell seals, plasma concentrations of this biomarker had decayed to a physiological baseline by the beginning of sample collection at $2 \mathrm{~d}$ p.p.

Based on a limited number of samples ( $\mathrm{n}=3$ for $\mathrm{AsB}$ and $\mathrm{n}=10$ for TMAO), biomarker concentrations during the first week p.p. were used to calculate $95 \%$ confidence limits for maximal plasma concentrations of AsB and TMAO consistent with fasting. The fasting limit for AsB calculated from samples collected during the first week of lactation represents a conservative estimate, because plasma AsB concentrations may be expected to continue to decline in animals that continue to fast, for example in Seal 318 (Fig. 4A). It is therefore unlikely that animals were erroneously classified as feeding, although it is possible that feeding animals were mis-classified as fasting in mid- and late lactation as a result of setting the fasting limit for plasma AsB too high. The fasting limit for TMAO is well supported, given the greater number of samples and lack of change in plasma TMAO concentrations during the first week p.p. More rapid elimination of
TMAO means that seals would be erroneously classified as fasting if sample collection took place too long after food consumption and animals fed infrequently. However, since there was good agreement between the proportion of seals classified as feeding during late lactation using either AsB or TMAO values (Table 1), this potential error appears to have been minimal.

Classification of lactating Weddell seals as feeding or fasting using the biomarker method produced 3 main results with regard to the prevalence and onset of feeding during lactation in this species:

Firstly, markedly (ca. 10-fold) higher mean plasma biomarker concentrations in late lactation compared with early lactation indicate that Weddell seals commence foraging during the lactation period. Given the estimated biological half-life values of AsB and TMAO, increases in plasma biomarker concentrations at $3 \mathrm{wk}$ p.p. and later can only derive from recent food intake and not from food consumed prior to parturition. Also, good agreement between estimates of feeding based on either AsB or TMAO in late lactation, and a close correlation between AsB and TMAO concentrations in plasma (Pearson correlation: $r=0.88, p<0.001$; Fig. 6) support the proposition that food intake typically took place shortly before sample collection. If feeding was infrequent, faster elimination of TMAO relative to AsB should result in greater discrepancy between the 2 biomarkers than was observed (note the discrepancy in biomarker concentration in Seal 821 at 9 d p.p. and in Seal 572 at 38 d p.p. [Fig. 4B]).

Secondly, both longitudinal and cross-sectional samples indicate that the initial fast lasts for 3 to $4 \mathrm{wk}$ in most but not all lactating Weddell seals studied. With the exception of 1 animal (Seal 572), females monitored for at least the first 3 wk p.p. $(n=6)$ fasted during this period. One female was only studied until $14 \mathrm{~d}$ p.p. and fasted during this time (Fig. 3). Seal 318 fasted at least until 23 d p.p. and appeared to forage for the remainder of the study. Seal 572 foraged throughout the study period from 14 to $38 \mathrm{~d}$ p.p., or more than $50 \%$ of the estimated lactation period in this species. Between 8 and 14 d p.p., 2 of 5 lactating females sampled were suspected to be feeding at 9 d p.p. (Fig. 2). After 4 wk p.p., approximately $70 \%$ of the sample population had fed recently.

Thirdly, the interpretation of elevated plasma AsB concentrations as indicative of re-feeding in animals during late lactation is supported by comparison with plasma concentrations of IGF1 (Fig. 5). Circulating IGF1 concentrations fall in response to a reduction in intake of protein or energy or both in rats, cats, dogs, domestic ruminants, humans, and northern elephant seal pups, and are restored by refeeding (Eigenmann et al. 1985, Thissen et al. 1994, Maxwell et al. 1998, 1999, Breier 1999, Filho et al. 1999, Frystyk et al. 1999, 
Friedl et al. 2000, Ortiz et al. 2003). Hence if elevated AsB concentrations in Weddell seals during late lactation signalled re-feeding, then a positive correlation should exist between circulating levels of AsB and IGF1. Although the comparison could be made only for a small number of lactating females $(\mathrm{n}=6)$, there was a strong positive correlation between plasma concentrations of AsB and IGF1 (Pearson correlation, $\mathrm{r}=0.96$, $\mathrm{p}<0.01)$.

Taken together, these findings suggest that (1) a large proportion of lactating Weddell seals in the study population commence foraging after 3 to $4 \mathrm{wk}$ p.p., (2) individual Weddell seals may forage as early as $9 \mathrm{~d}$ p.p., and (3) it is possible that some Weddell seals may consume little or no food during lactation. The last point is suggested by the observation that ca. $30 \%$ of females sampled after $27 \mathrm{~d}$ p.p. and 30 to $40 \%$ of females sampled after 35 d p.p. had biomarker levels below the fasting limits.

\section{Comparison with dive records}

Results of simultaneous monitoring of dive activity and biomarker levels in 2 lactating Weddell seals revealed that although dive activity corresponded with food intake in general, diving per se did not equate to food intake. For example, Seal 318 (Fig. 4A) commenced diving at $8 \mathrm{~d}$ p.p. but did not start foraging until 23 to $26 \mathrm{~d}$ p.p. Although criteria for distinguishing feeding dives from other dives have been proposed (Kooyman 1967, Schreer \& Testa 1996, Hindell et al. 2002), these criteria in general lack independent confirmation (Andrews 1998) or may be contradicted by direct evidence from underwater cameras (Davis et al. 1999), e.g. the assumption that Weddell seals feed only at depths greater than $50 \mathrm{~m}$ (Sato et al. 2002). In Seal 572 (Fig. 4B), periods of intensive diving were followed by both increases and decreases in observed biomarker levels, suggesting that not all foraging attempts were successful. The divergence of plasma concentrations of AsB and TMAO at 22 and $38 \mathrm{~d}$ with relatively low TMAO levels is probably due to the faster elimination of TMAO and suggests that little or no food was caught during the day preceding sample collection. Further concurrent studies of biomarkers and dive activity are required to elucidate the relationships of food intake and dive depth, dive profiles, and dive frequency.

\section{Biological relevance of findings}

A large percentage of the Weddell seals we studied fed during lactation, in agreement with theoretical considerations of energy and substrate requirements of lactating females that suggest that an unknown but possibly significant proportion of breeding females has insufficient body stores to complete lactation without feeding (Eisert 2003). However, the close correlation between maternal mass loss and pup mass gain observed by Tedman \& Green (1987) in Weddell seal females of large initial size suggests ingestion of little or no food during lactation (Tedman \& Green 1987, Testa et al. 1989, Bowen et al. 2001a). Our observation that ca. $30 \%$ of lactating Weddell seals sampled during the latter half of lactation appeared to be fasting is consistent with the possible co-existence of capital (fasting) and mixed income-capital (foraging) lactation strategies within the study population. Capital breeding strategies, of which fasting lactation is an extreme example, are considered advantageous when the availability of food during the critical period is poor or unpredictable, whereas income breeding strategies are favoured when there is dependable access to food (Jönsson 1997). Results in lactating harbour seals Phoca vitulina, a species that forages during lactation, indicate that feeding does not fully compensate for smaller body stores in lighter females and that pup mass gain and pup weaning mass depend primarily on initial maternal body mass despite foraging by lactating females (Bowen et al. 2001b). There are currently insufficient data to assess to what extent lactating Weddell seals depend on supplementary feeding to complete lactation. A strong dependency, in some or all females, on local food resources for successful lactation might limit breeding colonies to areas of local prey abundance, or result in vulnerability of populations to annual or long-term changes in prey availability, as might occur due to changes in sea ice or shifts in water currents.

\section{Limitations of the dietary biomarker method}

Circulating biomarker levels depend primarily on 4 factors: (1) concentrations in prey, (2) amount and type of prey ingested, (3) kinetics of uptake and elimination and (4) time of sampling relative to time of food consumption. It is therefore possible to fail to detect food intake with the biomarker method if the food consumed contains low or zero biomarkers, if the amount consumed was small, or if samples are collected too soon (before absorption) or too late (after elimination) relative to the feeding event. Fortunately, both AsB and TMAO are virtually ubiquitous in marine biota, and using several biomarkers reduces the risk of failing to detect food consumption. Further work is required to extend our knowledge of biomarker concentrations in prey, and possible sources of variability 
(ontogeny, season, reproductive status, habitat, etc.). It is also essential to quantify kinetics of uptake and elimination of dietary biomarkers in pinnipeds and other marine mammals, and how kinetics may be affected by meal size, activity (e.g. diving vs. resting), species, body size, and other factors.

Lack of data on the kinetics and the dose-response relationship of dietary biomarkers in marine mammals currently precludes accurate estimation of the minimum food intake detectable with the biomarker method. However, assuming that AsB distributes into total body water, we estimate that consumption of $1 \mathrm{~kg}$ of prey containing 1 ppm AsB-As (Table 2) should be detectable for at least $24 \mathrm{~h}$ after feeding in a $400 \mathrm{~kg}$ Weddell seal. For comparison, fish consumption in the adult Weddell seal may exceed $50 \mathrm{~kg}$ in a day (Caelhaem \& Christoffel 1969). TMAO is present in such high concentrations in marine biota (Table 3 ) that food consumption by a fasting animal is likely to be detected for even small intakes as long as sample collection takes place within $12 \mathrm{~h}$ after feeding. Hopefully, these estimates can be refined as data on biomarker kinetics in marine mammals become available.

The simplified method of analysis for AsB presented here measures quaternary arsonium compounds (QACs) and thus may include compounds other than AsB. However, QACs other than AsB are also strictly dietary and are rarely present in more than trace amounts, with AsB accounting for $>95 \%$ of QACs in almost all marine animals studied (see Table 2 and references therein). The analytical method presented in this study requires relatively simple sample preparation and only moderately expensive instrumentation (GF-AAS) and may therefore be of greater practical use than more complex methods that measure individual QACs (e.g. Ackley et al. 1999, Ebdon et al. 1999, Gómez-Ariza et al. 2000).

\section{Potential applications of the dietary biomarker method}

Because the dietary biomarker method only requires collection of plasma samples, it is well suited to test the effect of individual variables, such as body mass, on foraging activity in species with income or mixed income/capital lactation strategies, whether in crosssectional studies or in longitudinal studies of individual animals over long periods of time. The biomarker method can also provide an independent confirmation of food intake if used together with other methods of estimating foraging activity, such as isotopic methods (Bowen et al. 2001b) or 2- and 3-dimensional TDRs (Schreer \& Testa 1996, Hindell et al. 2002, Davis et al. 2003).
AsB is the single most abundant arsenical in liver, muscle and kidney in all predatory marine amniotes studied, including seals, cetaceans, sea birds, and sea turtles (Edmonds et al. 1994, Ebisuda et al. 2002, Kubota et al. 2002, 2003). Thus AsB may be a useful biomarker for species feeding on a wide range of prey including fish and cephalopods (e.g. odontocetes, phocid seals), benthic invertebrates (e.g. walrus, bearded seal), pelagic crustaceans (e.g. fur seals, penguins), zooplankton (baleen whales) and cnidarians (e.g. sea turtles). AsB distributes in soft tissues including adipose tissue (Vahter et al. 1983, Brown et al. 1990, Ebisuda et al. 2003), suggesting that this biomarker could potentially be measured in tissue samples instead of blood plasma. Thus it may be possible to apply the biomarker method to marine amniotes from which dart biopsies but not blood samples can be collected, such as the large whales.

Acknowledgements. We thank the following individuals who provided essential and much-appreciated help in the field and in the laboratory: J. Banks, D. Geddes, S. Leslie, C. McEntyre, B. Stewart, H. Stocklowienski, and in particular P. Isherwood and M. Jakubasz. Special thanks are also due to P. George, G. Moore and T. Walmsley of Canterbury Health Laboratories for their support and constructive comments, and to J. Plötz of the Alfred-Wegener-Institut for his role in this collaborative effort. We also thank D. Siniff, T. Gelatt and $\mathrm{M}$. Cameron for access to tagging records, and M. Power and our anonymous reviewers for comments on a draft of the paper. This research was supported by Antarctica New Zealand, and grants by the New Zealand Lottery Grants Board, the Health Research Council of New Zealand, the Smithsonian Office of Fellowships, the Friends of the National Zoo, the Christensen Fund, and the NZ/FRG Scientific and Technological Co-operation Agreement Programme.

\section{LITERATURE CITED}

Ackley KL, B'Hymer C, Sutton KL, Caruso JA (1999) Speciation of arsenic in fish tissue using microwave-assisted extraction followed by HPLC-ICP-MS. J Anal At Spectrom 14:845-850

Ágústsson I, Strøm AR (1981) Biosynthesis and turnover of trimethylamine oxide in the teleost cod, Gadus morhua. J Biol Chem 256:8045-8049

Al-Waiz M, Ayesh R, Mitchell SC, Idle JR, Smith RL (1987a) Disclosure of the metabolic retroversion of trimethylamine $\mathrm{N}$-oxide in humans: a pharmacogenetic approach. Clin Pharmacol Ther 42:608-612

Al-Waiz M, Mitchell SC, Idle JR, Smith RL (1987b) The metabolism of ${ }^{14} \mathrm{C}$-labelled trimethylamine and its $N$ oxide in man. Xenobiotica 17:551-558

Al-Waiz M, Mikov M, Mitchell SC, Smith RL (1992) The exogenous origin of trimethylamine in the mouse. Metabolism 41:135-136

Andrews RD (1998) Remotely releasable instruments for monitoring the foraging behaviour of pinnipeds. Mar Ecol Prog Ser 175:289-294

Anthoni U, Christophersen C, Gram L, Nielsen NH, Nielsen P (1991) Poisonings from flesh of the Greenland shark 
Somniosus microcephalus may be due to trimethylamine. Toxicon 29:1205-1212

Baskakov IV, Wang AJ, Bolen DW (1998) Trimethylamine Noxide counteracts urea effects on rabbit muscle lactate dehydrogenase function: a test of the counteraction hypothesis. Biophys J 74:2666-2673

Bengtson JL, Stewart BS (1992) Diving and haulout behavior of crabeater seals in the Weddell Sea, Antarctica, during March 1986. Polar Biol 12:635-644

Benramdane L, Accominotti M, Fanton L, Malicier D, Vallon JJ (1999) Arsenic speciation in human organs following fatal arsenic trioxide poisoning - a case report. Clin Chem 45:301-306

Blum WF, Breier BH (1994) Radioimmunoassays for IGFs and IGFBPs. Growth Regulat 4:11-19

Boness DJ, Bowen WD (1996) The evolution of maternal care in pinnipeds. Bioscience 46:645-654

Bornemann H (1994) Untersuchungen zum Fressverhalten der Weddellrobbe (Leptonychotes weddellii) in der Antarktis. PhD thesis, Freie Universität Berlin, Berlin

Bornemann H, Plötz J (1993) A field method for immobilizing Weddell seals. Wildl Soc Bull 21:437-441

Bornemann H, Mohr E, Plötz J (1992) Monitoring the feeding behavior of freely diving Weddell seals (Leptonychotes weddellii). J Vet Med A 39:228-235

Bornemann H, Mohr E, Plötz J, Krause G (1998) The tide as zeitgeber for Weddell seals. Polar Biol 20:396-403

Bowen WD, Ellis SL, Iverson SJ, Boness DJ (2001a) Maternal effects on offspring growth rate and weaning mass in harbour seals. Can J Zool 79:1088-1101

Bowen WD, Iverson SJ, Boness DJ, Oftedal OT (2001b) Foraging effort, food intake and lactation performance depend on maternal mass in a small phocid seal. Funct Ecol 15: 325-334

Bowen WD, Tully D, Boness DJ, Bulheier BM, Marshall GJ (2002) Prey-dependent foraging tactics and prey profitability in a marine mammal. Mar Ecol Prog Ser 244: 235-245

Boyd IL (1998) Time and energy constraints in pinniped lactation. Am Nat 152:717-728

Boyd IL (2000) State-dependent fertility in pinnipeds: contrasting capital and income breeders. Funct Ecol 14:623-630

Breier BH (1999) Regulation of protein and energy metabolism by the somatotropic axis. Dom Anim Endocrinol 17: 209-218

Breier BH, Gallaher BW, Gluckman PD (1991) Radioimmunoassay for insulin-like growth factor-I: solutions to some potential problems and pitfalls. J Endocrinol 128: 347-357

Brown RM, Newton D, Pickford CJ, Sherlock JC (1990) Human metabolism of arsenobetaine ingested with fish. Hum Exp Toxicol 9:41-46

Burg MB (1995) Molecular basis of osmotic regulation. Am J Physiol 268:F983-F996

Caelhaem I, Christoffel DA (1969) Some observations of the feeding habits of a Weddell seal, and measurements of its prey Dissostichus mawsoni at McMurdo Sound, Antarctica. NZ J Mar Freshw Res 3:181-190

Cannon JR, Saunders JB, Toia RF (1983) Isolation and preliminary toxicological evaluation of arsenobetaine-the water-soluble arsenical constituent from the hepatopancreas of the western rock lobster. Sci Total Environ 31: 181-185

Carr WES, Netherton JC, Gleeson RA, Derby CD (1996) Stimulants of feeding behavior in fish: analyses of tissues of diverse marine organisms. Biol Bull (Woods Hole) 190: $149-160$
Cline DR, Siniff DB, Erickson AW (1969) Immobilization and collecting blood from antarctic seals. J Wildl Manage 33: 138-144

Costa DP, Le Boeuf BJ, Huntley AC, Ortiz CL (1986) The energetics of lactation in the northern elephant seal, Mirounga angustirostris. J Zool (Lond) 209:21-33

Crocker DE, Williams JD, Costa DP, Le Boeuf BJ (2001) Maternal traits and reproductive effort in northern elephant seals. Ecology 82:3541-3555

Cullen WR, Reimer KJ (1989) Arsenic speciation in the environment. Chem Rev 89:713-764

Davis RW, Fuiman LA, Williams TM, Collier SO, Hagey WP, Kanatous SB, Kohin S, Horning M (1999) Hunting behaviour of a marine mammal beneath the antarctic fast ice. Science 283:993-996

Davis RW, Fuiman LA, Williams TM, Horning M, Hagey W (2003) Classification of Weddell seal dives based on 3dimensional movements and video-recorded observations. Mar Ecol Prog Ser 264:109-122

Deaker M, Maher W (1999) Determination of arsenic in arsenic compounds and marine biological tissues using low volume microwave digestion and electrothermal atomic absorption spectrometry. J Anal At Spectrom 14: 1193-1207

Ebdon L, Fisher A, Roberts NB, Yaqoob M (1999) Determination of organoarsenic species in blood plasma by HPLC/ ICP MS. Appl Organomet Chem 13:183-187

Ebisuda K, Kunito T, Kubota R, Tanabe S (2002) Arsenic concentrations and speciation in the tissues of ringed seals (Phoca hispida) from Pangnirtung, Canada. Appl Organomet Chem 16:451-457

Ebisuda K, Kunito T, Fujihara J, Kubota R, Shibata Y, Tanabe S (2003) Lipid-soluble and water-soluble arsenic compounds in blubber of ringed seal (Pusa hispida). Talanta 61:779-787

Edmonds JS, Francesconi KA (1988) The origin of arsenobetaine in marine animals. Appl Organomet Chem 2: 297-302

Edmonds JS, Francesconi KA (1993) Arsenic in seafoods: human health aspects and regulations. Mar Pollut Bull 26: 665-674

Edmonds JS, Shibata Y, Prince RIT, Francesconi KA, Morita M (1994) Arsenic compounds in tissues of the leatherback turtle, Dermochelys coriacea. J Mar Biol Assoc UK 74: 463-466

Edmonds JS, Shibata Y, Francesconi KA, Rippingale RJ, Morita M (1997) Arsenic transformations in short marine food chains studied by HPLC-ICP MS. Appl Organomet Chem 11:281-287

Eigenmann JE, de Bruijne JJ, Froesch ER (1985) Insulin-like growth factor I and growth hormone in canine starvation. Acta Endocrinol 108:161-166

Eisert R (2003) Energy metabolism of Weddell seals (Leptonychotes weddellii) during the lactation period. $\mathrm{PhD}$ thesis, Lincoln University, Canterbury, New Zealand

Fan TW, Colmer TD, Lane AN, Higashi RM (1993) Determination of metabolites by ${ }^{1} \mathrm{H}$ NMR and GC: analysis for organic osmolytes in crude tissue extracts. Anal Biochem 214:260-271

Fedak MA, Anderson SS (1982) The energetics of lactation: accurate measurements from a large wild mammal, the grey seal (Halichoerus grypus). J Zool (Lond) 198:473-479

Filho JC, Hazel SJ, Anderstam B, Bergstrom J, Lewitt M, Hall K (1999) Effect of protein intake on plasma and erythrocyte free amino acids and serum IGF-I and IGFBP-1 levels in rats. Am J Physiol 277:E693-701

Francesconi KA (2003) Complete extraction of arsenic spe- 
cies: a worthwhile goal? Appl Organomet Chem 17: $682-683$

Francesconi KA, Edmonds JS (1987) The identification of arsenobetaine as the sole water-soluble arsenic constituent of the tail muscle of the western king prawn Penaeus latisulcatus. Comp Biochem Physiol C 87:345-347

Francesconi KA, Gailer J, Edmonds JS, Goessler W, Irgolic KJ (1999) Uptake of arsenic-betaines by the mussel Mytilus edulis. Comp Biochem Physiol C 122:131-137

Friedl KE, Moore RJ, Hoyt RW, Marchitelli LJ, MartinezLopez LE, Askew EW (2000) Endocrine markers of semistarvation in healthy lean men in a multistressor environment. J Appl Physiol 88:1820-1830

Frystyk J, Delhanty PJD, Skjærbæk C, Baxter RC (1999) Changes in the circulating IGF system during short-term fasting and refeeding in rats. Am J Physiol 277:E245-E252

Fujihara J, Kunito T, Kubota R, Tanabe S (2003) Arsenic accumulation in livers of pinnipeds, seabirds and sea turtles: subcellular distribution and interaction between arsenobetaine and glycine betaine. Comp Biochem Physiol C 136:287-296

Geraci JR (1971) Functional hematology of the harp seal Pagophilus groenlandicus. Physiol Zool 44:162-170

Goessler W, Kuehnelt D, Schlagenhaufen C, Slejkovec Z, Irgolic KJ (1998a) Arsenobetaine and other arsenic compounds in the National Research Council of Canada Certified Reference Materials DORM 1 and DORM 2. J Anal At Spectrom 13:183-187

Goessler W, Rudorfer A, Mackey EA, Becker PR, Irgolic KJ (1998b) Determination of arsenic compounds in marine mammals with high-performance liquid chromatography and an inductively coupled plasma mass spectrometer as element-specific detector. Appl Organomet Chem 12: 491-501

Gómez-Ariza JL, Sánchez-Rodas D, Giráldez I, Morales E (2000) Comparison of biota sample pretreatments for arsenic speciation with coupled HPLC-HG-ICP-MS. Analyst 125:401-407

Hanaoka K, Fujita T, Matsuura M, Tagawa S, Kaise T (1987) Identification of arsenobetaine as a major arsenic compound in muscle of two demersal sharks, shortnose dogfish Squalus brevirostris and starspotted shark Mustelus manazo. Comp Biochem Physiol B 86:681-682

Hanaoka K, Goessler W, Ohno H, Nakatani Y, Ueno S, Kuehnelt D, Schlagenhaufen C, Irgolic KJ (1999) Occurrence of a few organo-arsenicals in jellyfish. Appl Organomet Chem 13:95-99

Happer DAR, Hayman CM, Storer MK, Lever M (2004) Aracyl triflates as derivatising agents for biological betaines. Aust J Chem 57:467-472

Harcourt RG, Hindell MA, Bell DG, Waas JR (2000) Threedimensional dive profiles of free-ranging Weddell seals. Polar Biol 23:479-487

Hatton AD, Gibb SW (1999) A technique for the determination of trimethylamine $\mathrm{N}$-oxide in natural waters and biological media. Anal Chem 71:4886-4891

Hedd A, Gales R, Renouf D (1996) Can stomach temperature telemetry be used to quantify prey consumption by seals? A re-examination. Polar Biol 16:261-270

Hill SEB (1987) Reproductive ecology of Weddell seals (Leptonychotes weddelli) in McMurdo Sound, Antarctica. PhD thesis, University of Minnesota, Minneapolis, MN

Hindell MA, Slip DJ, Burton HR (1991) The diving behavior of adult male and female southern elephant seals, Mirounga leonina (Pinnipedia: Phocidae). Aust J Zool 39:595-619

Hindell MA, Harcourt R, Waas JR, Thompson D (2002) Finescale three-dimensional spatial use by diving, lactating female Weddell seals Leptonychotes weddellii. Mar Ecol Prog Ser 242:275-284

Hindmarsh JT (2000) Arsenic, its clinical and environmental significance. J Trace Elem Exp Med 13:165-172

Holmes HC, Burns SP, Michelakakis H, Kordoni V, Bain MD, Chalmers RA, Rafter JE, Iles RA (1997) Choline and L-carnitine as precursors of trimethylamine. Biochem Soc Trans 25:96S

Jönsson KI (1997) Capital and income breeding as alternative tactics of resource use in reproduction. Oikos 78:57-66

Kaufmann GW, Siniff DB, Reichle R (1975) Colony behavior of Weddell seals, Leptonychotes weddellii, at Hutton Cliffs, Antarctica. In: Ronald K, Mansfield AW (eds) Biology of the seal. Rapp P-V Réun Cons Int Explor Mer 169:228-246

Kelly RH, Yancey PH (1999) High contents of trimethylamine oxide correlating with depth in deep-sea teleost fishes, skates, and decapod crustaceans. Biol Bull (Woods Hole) 196:18-25

Kirby J, Maher W (2002) Tissue accumulation and distribution of arsenic compounds in three marine fish species: relationship to trophic position. Appl Organomet Chem 16: 108-115

Kooyman GL (1967) An analysis of some behavioral and physiological characteristics related to diving in the Weddell seal. In: Llano GA, Schmitt WL (eds) Biology of the antarctic seas III, Vol 11. Antarctic Research Series. American Geophysical Union, Washington, DC, p 227-261

Kretzmann MB, Costa DP, LeBoeuf BJ (1993) Maternal energy investment in elephant seal pups: evidence for sexual equality? Am Nat 141:466-480

Kubota R, Kunito T, Tanabe S (2002) Chemical speciation of arsenic in the livers of higher trophic marine animals. Mar Pollut Bull 45:218-223

Kubota R, Kunito T, Tanabe S (2003) Occurrence of several arsenic compounds in the liver of birds, cetaceans, pinnipeds and sea turtles. Environ Toxicol Chem 22: 1200-1207

Lang F, Busch GL, Ritter M, Völkl H, Waldegger S, Gulbins E, Häussinger D (1998) Functional significance of cell volume regulatory mechanisms. Physiol Rev 78:247-306

Larsen EH, Pedersen GA, McLaren JW (1997) Characterization of National Food Agency shrimp and plaice reference materials for trace elements and arsenic species by atomic and mass spectrometric techniques. J Anal At Spectrom 12:964-968

Lee M, Blunt JW, Lever M, George PM (2004) A nuclearmagnetic-resonance-based assay for betaine-homocysteine methyltransferase activity. Anal Biochem 330: 199-205

Lehmann B, Ebeling E, Alsen-Hinrichs C (2001) Kinetik von Arsen im Blut des Menschen nach einer Fischmahlzeit [Kinetics of arsenic in human blood after a fish meal]. Gesundheitswesen 63:42-48

Lever M, Bason L, Leaver C, Hayman CM, Chambers ST (1992) Same-day batch measurement of glycine betaine, carnitine, and other betaines in biological material. Anal Biochem 205:14-21

Lever M, Sizeland PC, Frampton CM, Chambers ST (2004) Short and long-term variation of plasma glycine betaine concentrations in humans. Clin Biochem 37:184-190

Lindsey AA (1937) The Weddell seal in the Bay of Whales, Antarctica. J Mammal 18:127-144

Linnet K (1998) Performance of Deming regression analysis in case of misspecified analytical error ratio in method comparison studies. Clin Chem 44:1024-1031

Lundh T, Åkesson B, Skerfving S (1995) Effect of dietary intake of trimethylamine on human metabolism of the 
industrial catalyst dimethylethylamine. Occup Environ Med 52:478-483

Marshall GJ (1998) CRITTERCAM: an animal-borne imaging and data logging system. Mar Tech Soc J 32:11-17

Matsuto S, Stockton RA, Irgolic KJ (1986) Arsenobetaine in the red crab, Chionoecetes opilio. Sci Total Environ 48: 133-140

Maxwell A, Butterwick R, Yateman M, Batt RM, Cotterill A, Camacho-Hubner C (1998) Nutritional modulation of canine insulin-like growth factors and their binding proteins. J Endocrinol 158:77-85

Maxwell A, Butterwick R, Batt RM, Camacho-Hubner C (1999) Serum insulin-like growth factor (IGF)-I concentrations are reduced by short-term dietary restriction and restored by refeeding in domestic cats (Felis catus). J Nutr 129:1879-1884

Mellish JE, Iverson SJ (2001) Blood metabolites as indicators of nutrient utilization in fasting, lactating phocid seals: does depletion of nutrient reserves terminate lactation? Can J Zool 79:303-311

Mellish JE, Iverson SJ, Bowen WD, Hammill MO (1999) Fat transfer and energetics during lactation in the hooded seal: the roles of tissue lipoprotein lipase in milk fat secretion and pup blubber deposition. J Comp Physiol B 169: 377-390

Mitani Y, Sato K, Ito S, Cameron MF, Siniff DB, Naito Y (2003) A method for reconstructing three-dimensional dive profiles of marine mammals using geomagnetic intensity data: results from two lactating Weddell seals. Polar Biol 26:311-317

Mitchell SC, Zhang AQ, Noblet JM, Gillespie S, Jones N, Smith RL (1997) Metabolic disposition of $\left[{ }^{14} \mathrm{C}\right]$-trimethylamine N-oxide in rat: variation with dose and route of administration. Xenobiotica 27:1187-1197

Mohri T, Hisanaga A, Ishinishi N (1990) Arsenic intake and excretion by Japanese adults: a 7 -day duplicate diet study. Food Chem Toxicol 28:521-529

Nakazato T, Taniguchi T, Tao H, Tominaga M, Miyazaki A (2000) Ion-exclusion chromatography combined with ICPMS and hydride-generation-ICP-MS for the determination of arsenic species in biological matrices. J Anal At Spectrom 15:1546-1552

Nixon DE, Moyer TP (1992) Arsenic analysis II: rapid separation and quantification of inorganic arsenic plus metabolites and arsenobetaine from urine. Clin Chem 38: 2479-2483

Nnane IP, Damani LA (2001) Pharmacokinetics of trimethylamine in rats, including the effects of a synthetic diet. Xenobiotica 31:749-755

Norris ER, Benoit GJ, Jr. (1945) Studies on trimethylamine oxide. III. Trimethylamine oxide excretion by the rat. J Biol Chem 158:443-448

Oftedal OT (1993) The adaptation of milk secretion to the constraints of fasting in bears, seals and baleen whales. J Dairy Sci 76:3234-3246

Oftedal OT (1997) Lactation in whales and dolphins: evidence of divergence between baleen- and toothed-species. J Mammary Gland Biol Neopl 2:205-230

Oftedal OT (2000) Use of maternal reserves as a lactation strategy in large mammals. Proc Nutr Soc 59:99-106

Oftedal OT, Boness DJ, Tedman RA (1987) The behavior, physiology, and anatomy of lactation in the Pinnipedia. In: Genoways HH (ed) Current mammalogy, Vol 1, Chapter 6. Plenum Press, New York, p 175-245

Ortiz RM, Noren DP, Ortiz CL, Talamantes F (2003) GH and ghrelin increase with fasting in a naturally adapted species, the northern elephant seal (Mirounga angustirostris).
J Endocrinol 178:533-539

Plötz J, Bornemann H, Knust R, Schröder A, Bester M (2001) Foraging behaviour of Weddell seals, and its ecological implications. Polar Biol 24:901-909

Randall K, Lever M, Peddie BA, Chambers ST (1996) Accumulation of natural and synthetic betaines by a mammalian renal cell line. Biochem Cell Biol 74:283-287

Raymond JA (1994) Seasonal variations of trimethylamine oxide and urea in the blood of a cold-adapted teleost, the rainbow smelt. Fish Physiol Biochem 13:13-22

Raymond JA (1998) Trimethylamine oxide and urea synthesis in rainbow smelt and some other northern fishes. Physiol Zool 71:515-523

Raymond JA, de Vries AL (1998) Elevated concentrations and synthetic pathways of trimethylamine oxide and urea in some teleost fishes of McMurdo Sound, Antarctica. Fish Physiol Biochem 18:387-398

Sakurai T, Fujiwara K (2001) Modulation of cell adhesion and viability of cultured murine bone marrow cells by arsenobetaine, a major organic arsenic compound in marine animals. Br J Pharmacol 132:143-150

Sato K, Mitani Y, Cameron MF, Siniff DB, Watanabe Y, Naito $Y$ (2002) Deep foraging dives in relation to the energy depletion of Weddell seal (Leptonychotes weddellii) mothers during lactation. Polar Biol 25:696-702

Schreer JF, Testa JW (1996) Classification of Weddell seal diving behavior. Mar Mamm Sci 12:227-250

Seibel BA, Walsh PJ (2002) Trimethylamine oxide accumulation in marine animals: relationship to acylglycerol storage. J Exp Biol 205:297-306

Sheskin D (2000) Handbook of parametric and nonparametric statistical procedures, 2nd edn. Chapman \& Hall/CRC, Boca Raton, FL

Shibata Y, Morita M, Fuwa K (1992) Selenium and arsenic in biology: their chemical forms and biological functions. Adv Biophys 28:31-80

Shibata Y, Sekiguchi M, Otsuki A, Morita M (1996) Arsenic compounds in zoo- and phyto-plankton of marine origin. Appl Organomet Chem 10:713-719

Smith JL, Wishnock JS, Deen WM (1994) Metabolism and excretion of methylamines in rats. Toxicol Appl Pharmacol 125:296-308

Sokal RR, Rohlf FJ (1969) Biometry. WH Freeman, San Francisco, CA

Stirling I (1966) A technique for handling live seals. J Mammal 47:543-544

Súñer MA, Devesa V, Rivas I, Vélez D, Montoro R (2000) Speciation of cationic arsenic species in seafood by coupling liquid chromatography with hydride generation atomic fluorescence detection. J Anal At Spectrom 15:1501-1507

Súñer MA, Devesa V, Clemente MJ, Vélez D, Montoro R, Urieta I, Jalon M, Macho ML (2002) Organoarsenical species contents in fresh and processed seafood products. J Agric Food Chem 50:924-932

Svensson BG, Åkesson B, Nilsson A, Paulsson K (1994) Urinary excretion of methylamines in men with varying intake of fish from the Baltic Sea. J Toxicol Environ Health 41:411-420

Tedman R, Green B (1987) Water and sodium fluxes and lactational energetics in suckling pups of Weddell seals (Leptonychotes weddellii). J Zool (Lond) 212:29-42

Testa JW, Hill SEB, Siniff DB (1989) Diving behavior and maternal investment in Weddell seals (Leptonychotes weddellii). Mar Mamm Sci 5:399-405

Thissen JP, Ketelslegers JM, Underwood LE (1994) Nutritional regulation of the insulin-like growth factors. Endocr Rev 15:80-101 
Thomas J, DeMaster D (1983) Parameters affecting survival of Weddell seal pups (Leptonychotes weddelli) to weaning. Can J Zool 61:2078-2083

Treberg JR, Wilson CE, Richards RC, Ewart KV, Driedzic WR (2002) The freeze-avoidance response of smelt Osmerus mordax: initiation and subsequent suppression of glycerol, trimethylamine oxide and urea accumulation. J Exp Biol 205:1419-1427

Vahter M (1994) What are the chemical forms of arsenic in urine, and what can they tell us about exposure? Clin Chem 40:679-680

Vahter M, Marafante E, Dencker L (1983) Metabolism of arsenobetaine in mice, rats and rabbits. Sci Total Environ 30:197-211

Van Waarde A (1988) Biochemistry of non-protein nitrogenous compounds in fish including the use of amino acids for anaerobic energy production. Comp Biochem Physiol B 91:207-228

Welz B, Sperling M (1999) Atomic absorption spectrometry. Wiley-VCH, Weinheim

Welz B, Schlemmer G, Mudakavit JR (1988) Palladium nitrate-magnesium nitrate modifier for graphite furnace atomic absorption spectrometry. Part 1. Determination of arsenic, antimony, selenium and thallium in airborne particulate matter. J Anal At Spectrom 3:93-97

Wilkinson IS, van Aarde RJ (2001) Investment in sons and daughters by southern elephant seals, Mirounga leonina, at Marion Island. Mar Mamm Sci 17:873-887

Editorial responsibility: Otto Kinne (Editor-in-Chief), Oldendorf/Luhe, Germany
Withers PC, Morrison G, Hefter GT, Pang TS (1994) Role of urea and methylamines in buoyancy of elasmobranchs. J Exp Biol 188:175-189

Yancey PH, Siebenaller JF (1999) Trimethylamine oxide stabilizes teleost and mammalian lactate dehydrogenases against inactivation by hydrostatic pressure and trypsinolysis. J Exp Biol 202:3597-3603

Yancey PH, Somero GN (1980) Methylamine osmoregulatory solutes of elasmobranch fishes counteract urea inhibition of enzymes. J Exp Zool 212:205-213

Yancey PH, Clark ME, Hand SC, Bowlus RD, Somero GN (1982) Living with water stress: evolution of osmolyte systems. Science 217:1214-1222

Yoshida $\mathrm{K}$, Inoue $\mathrm{Y}$, Kuroda $\mathrm{K}$, Chen $\mathrm{H}$, Wanibuchi $\mathrm{H}$, Fukushima S, Endo G (1998) Urinary excretion of arsenic metabolites after long-term oral administration of various arsenic compounds to rats. J Toxicol Environ Health A 54: 179-192

Zeisel SH, DaCosta KA, Youssef M, Hensey S (1989) Conversion of dietary choline to trimethylamine and dimethylamine in rats: dose-response relationship. J Nutr 119:800-804

Zhang AQ, Mitchell SC, Smith RL (1999) Dietary precursors of trimethylamine in man: a pilot study. Food Chem Toxicol 37:515-520

Zhang X, Cornelis R, De Kimpe J, Mees L, Lameire N (1998) Study of arsenic-protein binding in serum of patients on continuous ambulatory peritoneal dialysis. Clin Chem 44 : 141-147

Submitted: August 26, 2004; Accepted: March 31, 2005

Proofs received from author(s): August 19, 2005 